Obituary

\title{
Dr. Behman Minoo Daver 1939-2015
}

write this obituary to cherish the memory of one of our eminent members Dr. BM Daver. He was born in 1939, educated initially at the BJ Medical College Pune, from where he qualified in 1964. Subsequent education was at the Sir JJ group of Hospitals including a rare distinction in MS Plastic Surgery after studying at the Tata Department of Plastic Surgery under the legendary Dr. NH Antia. In fact the next distinction in Bombay University was awarded to Dr. Manu Sood in 1989 almost 20 years later. He married his loving wife Ruby in 1976 and they have one daughter Ayesha who is now settled in the USA, sadly Mrs. Ruby Daver passed away some years before him. After his qualification he worked in the then prestigious Frenchay unit at Bristol in England and later went on to become a 'cleft fellow' with D. Ralph Millard in Miami Florida. On his return he became a Consultant at the Gokuldas Tejpal Hospital, a part of the academic teaching hospitals affiliated to the Grant Medical College Mumbai and subsequently headed the unit upon Dr. Maneksha's retirement.

He has several contributions to Plastic Surgery. I will name 3 although that is not all. A chapter in 1975 along with Dr. Antia about reconstructive surgery for nasal defects in the Clinics in Plastic Surgery. His great book on leprosy Surgery again with Dr. Antia and his own excellent work about palatal surgery where he did a very interesting study about whether pushed back muscles contract back or stay there. He was also an early pioneer in aesthetic surgery when people sniffed about it in front of residents and never really attempted to teach it. Instead for decades he conducted the famous GT rhinoplasty workshop jointly with Dr. Mrs Hakim an ENT surgeon and also his cousin. Generations of young plastic Surgeons got their first introduction to Rhinoplasty through this workshop.

It is important that we know him as a person rather than just the achievements. I am therefore including personal anecdotes which give an idea of this very upright man who also had a very subtle sense of humour. I came to know him in 1986 as my examiner for M.Ch. Plastic
Surgery. One of the fairest and most transparent exams I have ever seen in my life. As was the custom those days once news spread that Dr. Daver and Dr. Pandya were examiners their post graduate clinics suddenly saw a heightened attendance by the aspiring examinees from all units. He very calmly conducted clinics and one day tongue firmly in cheek told us, 'I know you are all here because I am rumoured to be the examiner but I also know what is practiced in your units and it would be wise to stick to that rather than miror my views if you want to pass safely'.

When Dr. NJ Pandya became president APSI in 1992 he called us all home for a meeting to decide on the organisation of the APSICON. Dr. Daver was appointed the Chair of the scientific committee and asked me to assist him in this endeavour. It was the most rewarding year for me in terms of experience in handling a meeting on national scale, on my own I decided to computerise the whole programme using Dbase III Plus, Dr. Daver had no clue about it but asked me if this would improve the way the scientific programme was conducted in APSICON 92. When I hesitantly replied in the affirmative, he was imediately supportive and made full use of the system if anything was good for APSI it always had his full and whole hearted support.

Subsequently he himself became the President of APSI in 1994 and appointed me again as his Organising secretary. With some hesitation I told him I was just about going to start practice, wondering if I could cope, without batting an eyelid he said 'excellent, now you will have plenty of time for this work' I did inded and in the depressing days of early practice I could pretend to be busy because I had this enormous task - pre email, pre mobile phone, basically with snail mail and the occasional fax. As an aside I recount a story which highlights his very proper side...A famous American surgeon wrote to me and said I should note that he is being acompanied by his 'significant other' and mentioned a ladies' name, having no idea what this meant I got on the phone and mentioned this - pat came 
the reply' none of our business Mukund' I said absolutely sir but Single room or two rooms...that got him! After a pause I was told 'single room and no need to discuss this elsewhere Mukund'.

India's honour was very important to him. During a WHO meeting he was asked if India could ever do a non hospital based survey of incidence of clefts. He agreed without hesitation. On his return I got called for lunch and the question was put to me. I said we would need funds for software, enumerators and so on. Immediately the Tata Trust was contacted and a grant made to APSI to fund this research. With this in hand we got proprietary software from Chennai and 8 units agreed to participate. He thus led the effort to do a survey of population centres for getting the true incidence of clefts in India. This led to two things, one was an eight centre survey which was a house to house survey - never ever conducted before which was subsequently reported to the WHO task force in Geneva and the subsequent monumental survey of an entire state led by Dr. K. Sridhar where the entire state of Tamil Nadu was covered. He and Mrs Ruby Daver were two of the most gracious people I have met and there was a lot I learnt from them about life and social mores.

Later on he became the Secretary general of the IPRAS Asian Pacific Section, a trustee of APSI as well as the President of the IPRAS Asian Pacific meeting in 2005 and Co-Chair of the world meeting in 2009 along with Dr. Suresh Gupta.
All thru his life he was an ardent nationalist and progress of APSI and India's honour in world Plastic Surgery scene were two subjects very close to his heart. Over innumerable lunches in Bombay Gym he would always be concerned over these two things and pushing for improvement and change.

He was a role model of ethical practice and a mentor to dozens of young plastic surgeons, both in Plastic Surgery as also about life and conduct in this world. We all have to go one day but thru these columns we mourn the loss of a true gem.

I salute his achievements and his memory and offer our collective condolences to Ayesha and the family.

Mukund R Thatte

Department of Plastic Surgery, Bombay Hospital, New Marine Lines Mumbai, Maharashtra, India

Address for correspondence: Dr. Mukund R Thatte, Accadamic Head of Plastic Surgery, Bombay Hospital Institute of Medical Sciences, Mumbai, Maharashtra, India. E-mail: mthatte@vsnl.com

\begin{tabular}{|l|l|}
\hline \multicolumn{2}{|c|}{ Access this article online } \\
\hline Quick Response Code: & Website: \\
\hline & www.ijps.org \\
\hline & \\
\hline
\end{tabular}

